\title{
First record of citrus canker, caused by Xanthomonas citri subsp. citri in Solomon Islands
}

\author{
R. I. Davis • R. K. Taylor $\cdot$ D. Rouse • M. Flack • \\ D. Hailstones • L. M. Jones • J. B. Rossel • C. Fanai • \\ F. Tsatsia $\cdot$ H. Tsatsia
}

Received: 21 October 2014 / Accepted: 15 December 2014 /Published online: 25 February 2015

(C) Australasian Plant Pathology Society Inc. 2015

\begin{abstract}
Citrus canker disease was detected for the first time in Solomon Islands on Guadalcanal Island. The bacterium was isolated from diseased citrus plants exhibiting distinct citrus canker symptoms consisting of crater-like lesions on the rind of fruit and corky yellow-brownish lesions on leaves. Xanthomonas citri subsp. citri was identified using biochemical and molecular tests and confirmed as the causal agent by fulfilling Koch's postulates.
\end{abstract}

Keywords Citrus canker - Xanthomonas citri subsp. citri . Solomon Islands

R. I. Davis $(\bowtie) \cdot$ L. M. Jones

Department of Agriculture, Northern Australia Quarantine Strategy

(NAQS), PO Box 96, Cairns International Airport, Qld 4870,

Australia

e-mail: richard.davis@agriculture.gov.au

R. K. Taylor $\cdot$ D. Rouse

Plant Health and Environment Laboratory, Ministry for Primary

Industries, PO Box 2095, Auckland 1140, New Zealand

M. Flack $\cdot$ D. Hailstones

Industry \& Investment NSW, Elizabeth Macarthur Agricultural

Institute, Private Bag 4008, Narellan, NSW 2567, Australia

J. B. Rossel

Department of Agriculture, International Plant Health Program, GPO

Box 858, Canberra City, ACT 2601, Australia

C. Fanai $\cdot$ F. Tsatsia

Biosecurity Solomon Islands (BSI), Ministry of Agriculture and

Livestock (MAL), PO Box G13, Honiara, Solomon Islands

H. Tsatsia

Agricultural Research Division (Plant Pathology), Ministry of Agriculture and Livestock (MAL), PO Box G13 Honiara, Solomon Islands
In May 2010, Biosecurity Solomon Islands (BSI) and the Australian Department of Agriculture conducted a plant health survey on the islands of Guadalcanal and Malaita. Symptoms of citrus canker disease, including raised and corky lesions on both leaf surfaces, with water-soaked margins and strong chlorotic haloes (Figs. 1, 2 and 3) were found at Visale, Guadalcanal. Affected trees included lemons, limes, oranges and mandarins. Citrus canker is caused by the bacterium Xanthomonas citri subsp. citri, previously known as $X$. axonopodis pv. citri and X. campestris pv. citri (Schaad et al. 2006). Citrus canker has not previously been reported from the Solomon Islands and its distribution in the Pacific is patchy, with records existing for only seven different countries /territories (Table 1).

Desiccated samples of young canker and leaf tissue from affected lemon (Citrus x limon) and orange (Citrus $\mathrm{x}$ aurantium) trees, were returned to Australia and subjected to mandatory gamma irradiation at $25 \mathrm{KGy}$. Nucleic acids were extracted using a Qiagen DNeasy Plant Mini Kit and screened by PCR using the primer pair J-pth 1/J-pth 2 (Cubero and Graham 2002) following the protocol from the Australian draft national standard. A PCR product of the expected size (197 bp) was produced. In confirmatory analyses in a second laboratory, this test was repeated successfully and a second assay, using the primer pair Xac01/Xac02 (Coletta-Filho et al. 2006), also gave a diagnostic fragment $(581 \mathrm{bp})$. The amplified fragments from all three reactions (two J-pth $1 / \mathrm{J}$-pth 2 products and one Xac01/Xac02 product) were purified and subjected to nucleotide sequence analysis, confirming that the bacterium was X.citri subsp. citri.

There are closely related bacteria that also cause similar, but less severe, canker diseases on a restricted range of citrus 


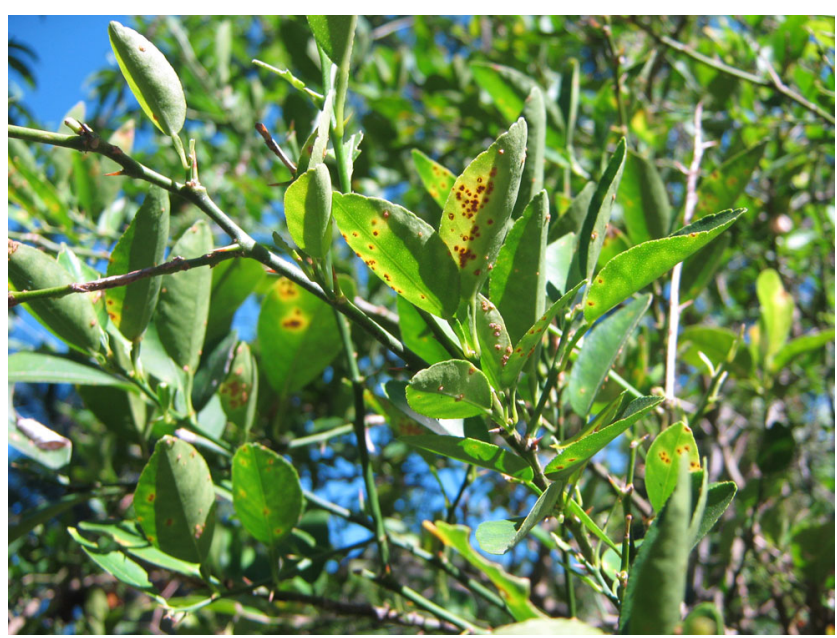

Fig. 1 Canker disease symptoms found on lemon (Citrus x limon) foliage at Visale, Guadalcanal, Solomon Islands, May 2010

elsewhere in the world, and one of these is now named X. fuscans subsp. aurantifolii (Schaad et al. 2006). Whilst the PCR assay of Cubero and Graham (2002) is known to also detect this bacterium, the second PCR assay (Coletta-Filho et al. 2006) is specific only for X.citri subsp. citri. These tests do not exclude the less damaging restricted host range variants of X.citri subsp. citri known as the $\mathrm{A}^{*}$ and $\mathrm{A}^{\mathrm{w}}$ pathotypes. However, the severity and wide host range observed in the field suggests that this must be the highly virulent, broad host range variant formerly known as the 'asiatic' or pathotype 'A' form of $X$. campestris pv. citri (Stall and Civerolo 1993). These observations were further supported by later analysis of Irp gene sequences which showed the Solomon Islands isolates closely matched the A pathotype and were distinct from the $\mathrm{A}^{*}$ and $\mathrm{A}^{\mathrm{w}}$ pathotypes (Fig. 4).

In later work, infected lemon and orange leaf and fruit material were sent to New Zealand, under relevant biosecurity protocols, and isolations were conducted in a biocontainment laboratory (Physical containment level 2 with additional controls). Saline suspensions of macerated diseased leaf and fruit tissues were streaked onto King's B media (King et al. 1954)

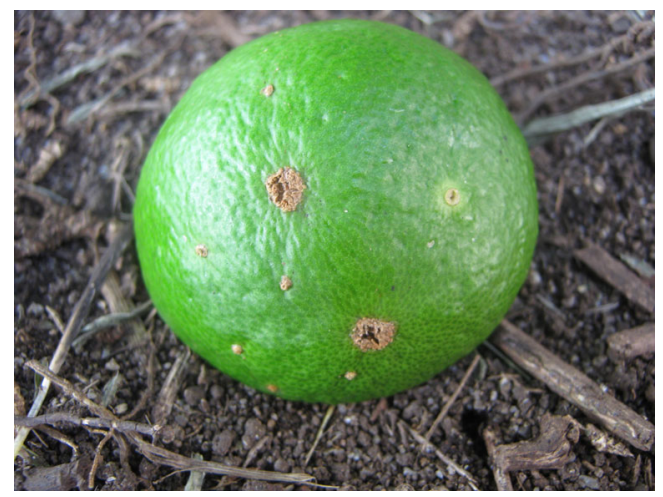

Fig. 2 Canker lesions on lime (Citrus x aurantiifolia) fruit

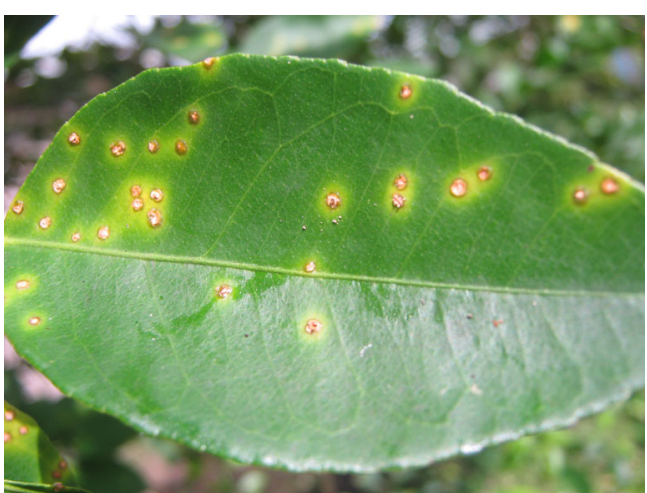

Fig. 3 Close up of canker lesions on a lime (Citrus x aurantiifolia) leaf

and mucoid pale yellow bacterial colonies were consistently grown following $48 \mathrm{~h}$ incubation at $25^{\circ} \mathrm{C}$. All colonies were gram negative, oxidase negative, catalase positive and produced levan from sucrose and tested positive for $X$. citri subsp. citri by real-time PCR assays, developed by Cubero and Graham (2005) and Mavrodieva et al. (2004). The gyrB and Irp gene sequences were amplified from pure bacterial cultures and analysis was conducted according to the methodology of Parkinson et al. (2009) and Cubero and Graham (2004). BLASTn analysis of the $\operatorname{gyrB}$ and $\operatorname{Irp}$ amplicons showed that they were $100 \%$ match to verified $X$. citri subsp. citri sequences in GenBank, for example, accession EU498950 for gyrB and AY227401 for Irp. X. citri subsp. citri was isolated consistently from lemon and orange tissue adjacent to leaf spots and fruit lesions. The cultures used in this study have been deposited in the International Collection of Microorganisms from Plants (ICMP), Landcare Research, Auckland, New Zealand. Pathogenicity tests with three isolates (ICMP 20576, 20577, 20578) were

Table 1 Summary of citrus canker records in the Pacific islands

\begin{tabular}{|c|c|c|}
\hline $\mathrm{PICT}^{\mathrm{A}}$ & Identification method & Citation \\
\hline CNMI & Biochemical testing ${ }^{\mathrm{B}}$ & Jenkins and Forsberg (1957) \\
\hline Fiji & Biochemical testing ${ }^{\mathrm{B}}$ & Dingley et al. (1981) \\
\hline \multirow[t]{2}{*}{ FSM } & Biochemical testing ${ }^{\mathrm{B}}$ & Jenkins and Forsberg (1957) \\
\hline & Molecular testing (PCR) & Anon (2001) \\
\hline \multirow[t]{2}{*}{ Guam } & Biochemical testing ${ }^{\mathrm{A}}$ & Jenkins and Forsberg (1957) \\
\hline & Molecular testing (PCR) & Coletta-Filho et al. (2006) \\
\hline Palau & Biochemical testing ${ }^{\mathrm{B}}$ & Jenkins and Forsberg (1957) \\
\hline \multirow[t]{2}{*}{ PNG } & Biochemical testing ${ }^{\mathrm{B}}$ & Shaw (1984) \\
\hline & Molecular testing (PCR) & Davis et al. (2000) \\
\hline RMI & Molecular testing (PCR) & Anon (2001) \\
\hline
\end{tabular}

${ }^{A}$ Pacific island country or territory: CNMI: Commonwealth of the Northern Mariana Islands, FSM: Federated States of Micronesia, PNG: Papua New Guinea, RMI: the Republic of the Marshall Islands

B Biochemical testing presumed: the published listing states that plant specimens were collected and lodged in collections following laboratory identifications, but specific identification methods are not detailed 


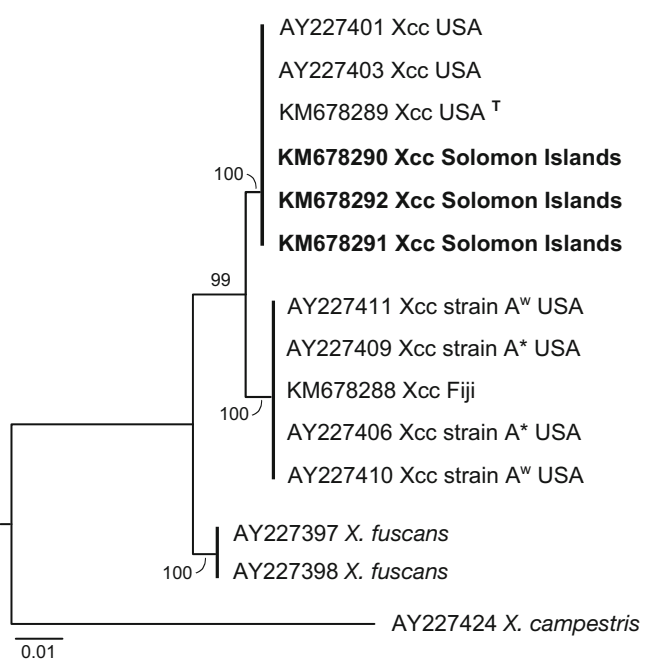

Fig. 4 Maximum likelihood tree illustrating the phylogenetic relationships between the Solomon Islands Xanthomonas citri subsp. citri (Xcc) strains (in bold type) and other Xcc strains. Phylogenetic analyses of the Irp gene were performed via the CIPRES Science Gateway (Miller et al. 2010), using the RAxML-HPC2 8.0.0 with the k option for bootstrap analysis. Topology was rooted with $X$. campestris and the bootstrap values are given at the nodes; superscripted $\mathrm{T}$ indicates the type strain. Sequences produced in this study are deposited in GenBank under accession numbers KM678288 - KM678292

performed on young detached leaves of orange, alemow (Citrus x macrophylla), pomelo (C. maxima), and lime (Citrus $\mathrm{x}$ aurantiifolia). Each isolate was inoculated onto three leaves by placing $20 \mu \mathrm{l}$ of bacterial suspension $\left(10^{7} \mathrm{cfu} / \mathrm{mL}\right)$ on the surface and pricking through the drops using sterile needles. After inoculation, the leaves were kept in Petri dishes lined with moist filter paper, incubated at $25^{\circ} \mathrm{C}$ and checked daily for symptoms. Controls were inoculated in the same way using sterile physiological saline $(0.85 \% \mathrm{NaCl})$. Lesions developed on the inoculated leaves for all varieties 7 days after inoculation (Fig. 5). The symptoms induced on leaves were similar to those caused by natural infections. Bacterial colonies were re-isolated from leaf lesions and identified as X. citri subsp. citri, fulfilling Koch's postulates. No symptoms developed in the negative controls. The pathogenicity tests were performed twice.

Following the 2010 survey, delimiting surveys on Guadalcanal found similar symptoms at several other locations at the west of the island and also in the capital, Honiara. Later citrus targeted surveys have covered much of the country and have

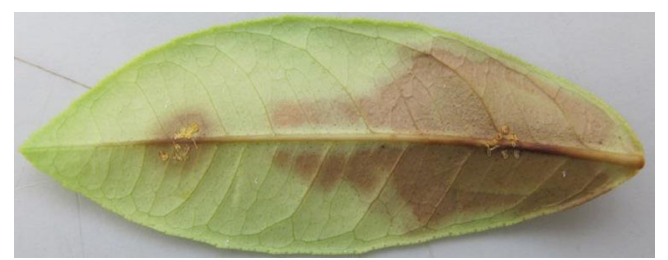

Fig. 5 Symptoms on detached Citrus aurantiifolia leaf inoculated with Solomon Island Xanthomonas citri subsp. citri isolate ICMP 20576
Table 2 Areas surveyed and found to be free of citrus canker symptoms by visual examination subsequent to initial identification of $X$. citri subsp. citri on Guadalcanal Island

Year Locations

2010 Malaita Island, Malaita Province

2011 Ghizo, Kolombangara, and Parara islands, Western Province

2012 Taro, Mono, Poporang, Shortland, Maleai, Fauro islands, Choiseul Province

2012 Vella Lavella, Kolombangara islands, Western Province

2013 Ngella and Savo islands, Central Province

2013 Santa Isabel island, Isabel Province

2013 Malaita Island, Malaita Province

2014 San Cristobal Island, Makira Province

2014 Nendo Island, Temotu Province

failed to find canker-like symptoms on any other island (Table 2). These included islands closest to PNG, where the disease has been widespread for many years (Shaw 1984), and movement of infected fruits or leaves across the border is a likely threat. Effective survival of $X$. citri subsp. citri inoculum in cankers on leaves under tropical conditions has been demonstrated (Pruvost et al. 2002).

The effects of citrus canker on individual tree yield and fruit quality can be great in large monoculture orchards (Gottwald et al. 1992). In contrast to this, the impact observed on isolated trees in subsistence / domestic production situations on several other Pacific islands is minimal (R. Davis unpublished data). For this reason, a strategy of containment rather than the difficult and costly eradication (Gottwald et al. 2002), might be most suitable for Solomon Islands.

Acknowledgments The Solomon Islands Government and the Australian Department of Agriculture's International Plant Health Program are gratefully thanked for funding and coordinating many aspects of the series of surveys. Mr George Harunari, Mr Japhet Tawo and Mr Gideon Suda, BSI, are also gratefully thanked for assistance in the field.

\section{References}

Anon (2001) 'Citrus bacterial canker (Xanthomonas axonopodis pv. citri) type A (Asiatic strain) reported from Kosrae, Federated States of Micronesia and Majuro, Republic of the Marshall Islands.' SPC PPS Pest Alert No. 22, August 2001. (Land Resources Division, Secretariat of the Pacific Community, Suva, Fiji Islands)

Coletta-Filho HD, Takita MA, de Souza AA, Neto JR, Destéfano SAL, Hartung JS, Machado MA (2006) Primers based on the rpf gene region provide improved detection of Xanthomonas axonopodis pv. citri in naturally and artificially infected citrus plants. J Appl Microbiol 100:279-285

Cubero J, Graham JH (2002) Genetic relationship among worldwide strains of Xanthomonas causing canker in citrus species and design of new primers for their identification by PCR. Appl Environ Microbiol 68:1257-1264 
Cubero J, Graham JH (2004) The leucine-responsive regulatory protein (lrp) gene for characterization of the relationship among Xanthomonas species. Int J Syst Evol Microbiol 54:429-437

Cubero J, Graham JH (2005) Quantitative real-time polymerase chain reaction for bacterial enumeration and allelic discrimination to differentiate Xanthomonas strains on citrus. Phytopathology 95:13331340

Davis RI, Hailstones DL, Jacobson SC, Eichner RH, Gunua TG, Rahamma S, Broadbent P (2000) Surveillance for citrus canker disease in New Guinea and northern Australia. Aust Plant Pathol 29: 222

Dingley JM, Fullerton RA, Mckenzie EHC (1981) Records of fungi, bacteria, algae and angiosperms pathogenic on plants in Cook Islands, Fiji, Kiribati, Niue, Tonga, Tuvalu and Western Samoa. South Pacific Bureau for Economic Cooperation/United Nations Development Programme/Food and Agriculture Organisation of the United Nations, Rome Italy

Gottwald TR, Reynolds KM, Campbell CL, Timmer LW (1992) Spatial and spatiotemporal analysis of citrus canker epidemics in citrus nurseries and groves in Argentina. Phytopathology 82:843-851

Gottwald TR, Graham JH, Schubert TS (2002) Citrus canker: the pathogen and its impact. Plant Health progress. Available at http://hdl. handle.net/10113/11855

Jenkins AE, Forsberg FR (1957) Records of citrus canker and sweetpotato stem and foliage scab in Micronesia. Plant Dis Report 41:1055-1056
King EO, Ward MK, Raney DE (1954) Two simple media for the demonstration of pyocyanin and fluorescein. J Lab Clin Med 44:301-307

Mavrodieva V, Levy L, Gabriel DW (2004) Improved sampling methods for real-time polymerase chain reaction diagnosis of citrus canker from field samples. Phytopathology 94:61-68

Miller MA, Pfeiffer W, Schwartz T (2010) Creating the CIPRES Science gateway for inference of large phylogenetic trees. Gateway Computing Environments Workshop (GCE), New Orleans

Parkinson N, Cowie C, Heeney J, Stead D (2009) Phylogenetic structure of Xanthomonas determined by comparison of gyrB sequences. Int $\mathrm{J}$ Syst Evol Microbiol 59:264-274

Pruvost O, Boher B, Brocherieux C, Nicole M, Chiroleu F (2002) Survival of Xanthomonas axonopodis pv. citri in leaf lesions under tropical environmental conditions and simulated splash dispersal of inoculum. Phytopathology 92:336-346

Schaad NW, Postnikova E, Lacy G, Sechler A, Agarkova I, Stromberg PE, Stromberg VK, Vidaver AK (2006) Emended classification of xanthomonad pathogens on citrus. Syst Appl Microbiol 29:690-695

Shaw DE (1984) 'Microorganisms in Papua New Guinea.' Research Bulletin No. 33, (Department of Primary Industry, Port Moresby, Papua New Guinea)

Stall RE, Civerolo EL (1993) Xanthomonas campestris pv. citri: cause of citrus canker. In: Swings JG, Civerolo EL (eds) Xanthomonas. Chapman and Hall, London 